\title{
PENGARUH KESEDIAAN BERBAGI PENGETAHUAN PADA SIKAP DALAM BEKERJA TIM
}

\author{
Dinda Amalia ${ }^{1}$ ) Hajan Hidayat ${ }^{2}$ ) \\ 1) Prodi Akuntansi Manajerial Politeknik Negeri Batam, email: damalia665@gmail.com \\ 2) Prodi Akuntansi Manajerial Politeknik Negeri Batam, email: hajan@ polibatam.ac.id
}

\begin{abstract}
Abtract
This study aims to determine the influence of willingness to share knowledge of attitudes in team work. In the measurement of attitude in team work, this study uses two dimensions that is perceptions of team performance effectiveness and student interest in team work. The research method used a quantitative method approach. This study uses primary data. The instrument method is Likert scale. Sampling research using purposive sampling method. The author set the number of samples to be studied at least 200 samples with the category of students who are in accounting majors. The results of this study indicate that the willingness to share knowledge affect the perceptions of the effectiveness of team work and willingness to share knowledge affect the student's interest in team work. Future research is expected to add a wider sample and can add an assessment dimension to the knowledge sharing willingness variable. This research can be used as consideration or as a reference and additional information for researchers who will conduct further research on team work.
\end{abstract}

Keywords: willingness to share knowledge, teamwork, attitude on teamwork

\begin{abstract}
Abstrak
Penelitian ini bertujuan untuk mengetahui pengaruh kesediaan berbagi pengetahuan terhadap sikap dalam bekerja tim. Dalam pengukuran sikap dalam bekerja tim, penelitian ini mengunakan dua dimensi yaitu persepsi keefektivan kinerja tim dan minat mahasiswa dalam bekerja tim. Metode penelitian menggunakan pendekatan metode kuantitatif. Penelitian ini menggunakan data primer. Metode penskalaan instrumen yang digunakan adalah skala likert. Penarikan sampel penelitian menggunakan metode purposive. Teknik penarikan sampel yang digunakan adalah purposive sampling dengan kriteria harus sudah pernah bekerjasama dalam tim dalam pengerjaan tugas kelompok di kelas dan merupakan mahasiswa/i ruang lingkup jurusan akuntansi. Penulis menetapkan jumlah sampel yang akan diteliti minimal 200 sampel dengan kategori yaitu mahasiswa/i yang dijadikan objek penelitian ini adalah mahasiswa/i dengan ruang lingkup jurusan akuntansi. Hasil penelitian ini menunjukkan bahwa kesediaan berbagi pengetahuan berpengaruh terhadap persepsi keefektivan kerja tim dan kesediaan berbagi pengetahuan berpengaruh terhadap minat mahasiswa dalam bekerja tim. Penelitian selanjutnya diharapkan untuk menambah sampel yang lebih luas dan dapat menambahkan dimensi penilaian terhadap variabel kesediaan berbagi pengetahuan. Penelitian ini dapat dijadikan bahan pertimbangan atau sebagai referensi dan tambahan informasi bagi peneliti yang akan melakukan penelitian selanjutnya mengenai kerja tim.
\end{abstract}

Kata kunci: kesediaan berbagi pengetahuan, kerja tim, etika dalam kerja tim. 


\section{PENDAHULUAN}

Dasar tujuan perusahaan adalah meningkatkan kinerja agar dapat mencapai tujuan perusahaan yaitu meningkatkan laba, dan mampu bertahan di tengah persaingan. Oleh sebab itu, perusahaan harus mampu memanfaatkan seluruh sumber daya yang dimiliki. Salah satu sumber daya yang sangat penting bagi perusahaan adalah karyawan. Kerja tim karyawan yang efektif dan efisien sangat diperlukan guna meningkatkan pencapaian perusahaan. Apabila tim kerja yang dimiliki tidak efektif dan efisien, maka akan menghambat pencapaian target perusahaan yang telah ditetapkan. Beberapa masalah yang dihadapi dalam tim kerja di perusahaan antara

lain persaingan antarkaryawan, sifat menghindari sebuah masalah, hilangnya tanggung jawab personal, reward yang dibagi rata terhadap seluruh karyawan, hilangnya koordinasi dan pembagian pekerjaan yang tidak adil. Masalah-masalah dalam tim kerja seringkali menimbulkan konflik. Konflik yang terjadi dalam tim kerja seperti meghancurkan pihak lain, serangan fisik secara agresif, ancaman dan ultimatum, serangan verbal secara kasar, terang-terangan menentang orang lain, dan ketidaksepakatan mampu menghambat kinerja tim (Robbins \& Judge, 2011). Setiap departemen dalam perusahaan membutuhkan kerja tim yang baik, hal itu menyebabkan departemen satu dengan departemen lainnya berhubungan erat dalam mencapai target perusahaan. Masalah kinerja dalam departemen akuntansi adalah masalah yang sangat penting. Keefektivan dalam tim kerja diperlukan adanya pengendalian yang baik dalam sistem penerapannya, seperti mind set, substance, work approach, process, tool, dan role. Departemen akuntansi yang telah menerapkan sistem pengendalian dengan baik, maka dapat menjadi tim kerja yang efektif sehingga mampu menghasilkan output yang dibutuhkan sesuai target, seperti laporan keuangan yang akurat, perencanaan keuangan tahunan, budgeting, dan manajemen biaya yang baik (Constantin, Geta, $\&$ Meier, 2014).

Mengingat pentingnya efektivitas kerja tim bagi perusahaan atau organisasi kemampuan bekerja tim yang baik sangat dibutuhkan. Pendidikan tinggi sebagai lembaga pencetak angkatan kerja diharapkan mampu untuk membentuk lulusan yang mampu bekerja tim dengan efektif. Kemampuan dalam bekerja tim akan sangat berguna kinerja mahasiswa di masa depan. Fullwood, Rowley, \& Delbridge (2013) mengatakan bahwa dapat meningkatkan kemampuan diri dalam bekerja sama sehingga dapat dijadikan sebagai nilai lebih setiap mahasiswa dalam dunia kerja. Yuen \& Majid (2007) mengatakan bahwa etika yang baik dalam kesediaan berbagi pengetahuan akan membuat mahasiswa memiliki nilai lebih yang sangat berguna dalam dunia kerja. Universitas harus memberikan kesempatan dan situasi informal sebua tim untuk mahasiswa agar dapat mempelajari pentingnya kesediaan berbagi pengetahuan dalam sebuah kerja tim dan elemen penting yang harus dimiliki setiap mahasiswa dalam dunia kerja (Yuen \& Majid, 2007). Penelitian Yuen \& Majid (2007) juga mengatakan bahwa kesediaan berbagi pengetahuan merupakan elemen dasar yang efektif dan sangat penting dalam mempelajari yang berkenaan dengan suatu jabatan. Dapat dipahami dari pernyataan tersebut bahwa, kesediaan berbagi pengetahuan harus menjadi bagian dari kepribadian dan harus diterapkan menjadi mindset dalam area kerja.

Berdasarkan penelitian tersebut dapat dipahami bahwa mahasiswa pada umumnya dan mahasiswa jurusan akuntansi perlu untuk terampil dalam bekerja tim karena dipersiapkan untuk menjadi tenaga ahli dan pimpinan di perusahaan-perusahaan dan instansi lainnya. Menurut Robbins \& Judge (2011) efektivitas tim ditentukan oleh 3 kategori yaitu konteks, komposisi, dan proses. Berkaitan dengan faktor komposisi, di dalamnya terdapat individuindividu yang membentuk tim. Individu tersebut menentukan efektivitas tim. Salah satu faktor dalam komposisi dalam tim yang sangat penting adalah sikap atau minat anggota untuk bekerja dalam tim. Menurut Yuen \& Majid (2007) setiap individu dari kelompok harus memahami bahwa kesediaan berbagi pengetahuan sangat bermanfaat bagi tim kerja dan memiliki pengaruh positif terhadap proses belajar mengajar dalam sebuah tim kerja dan merupakan sebuah metode yang efektif dalam pembelajaran sebuah tim. Yuen \& Majid (2007) juga mengatakan setiap anggota tim harus mampu memahami bahwa kesediaan berbagi pengetahuan merupakan sebuah elemen penting bagi setiap tim kerja. 
Dinda \& Hajan, pengaruh kesediaan berbagi pengetahuan pada sikap dalam bekerja tim...

Mengingat pengaruh sikap atau minat bekerja tim yang sangat penting dalam menentukan efektivitas kerja tim beberapa penelitian telah dilakukan. Penelitian Pineda \& Lerner (2006) menemukan bahwa mahasiswa yang terikat dalam tim dapat mengembangkan sikap bekerja tim dan merasa bahwa belajar dalam sebuah tim sangat efektif. Penelitian Rudawska (2016) bertujuan untuk mengevaluasi pengaruh dari pengalaman kerja tim terhadap sikap bekerja tim, yang diukur dari persepsi kefektifan kerja tim dan minat dalam bekerja tim. Hasil dari penelitian tersebut menyatakan bahwa kepemimpinan dalam tim dan kondisi tim kerja yang baik berpengaruh pada keefektivan tim kerja dan keadilan pembagian pekerjaan dalam tim berpengaruh pada minat mahasiswa dalam bekerja sama. Penelitian Park (2012) menemukan bahwa terdapat hubungan antara kemampuan mengatur tim dengan sikap yang kerja atau minat kerja yang terdapat dalam tim. Kepercayaan antar anggota tim memengaruhi sikap anggota dalam bekerja secara tim (Kiffin, Petersen, \& Cordery, 2003). Berdasarkan uraian penelitian di atas, terdapat alasan penelitian ini sangat penting dilakukan yaitu: pertama, faktor sikap dan minat bekerja tim merupakan faktor individu yang penting dalam mempengaruhi efektivitas tim. Kedua, pentingnya untuk meneliti faktor-faktor individu lainnya yang menentukan sikap dan minat bekerja tim sehingga didapatkan gambaran yang lebih lengkap. Ketiga, belum adanya penelitian yang mencoba meneliti faktor kesediaan berbagi pengetahuan untuk diteliti pengaruhnya terhadap sikap dan minat bekerja tim. Keempat, adanya saran dari penelitian yang dilakukan oleh Rudawska (2016) yang mana peneliti selanjutnya penting untuk melihat dan melengkapi penelitian dengan variabel kesediaan berbagi pengetahuan terhadap sikap dan minat bekerja tim.

\section{Perumusan Masalah}

Berdasarkan pendahuluan yang telah diuraikan tersebut, maka rumusan masalah dalam penelitian ini adalah pertama bagaimana pengaruh kesediaan berbagi pengetahuan terhadap persepsi keefektivan kinerja tim, kedua bagaimana pengaruh kesediaan berbagi pengetahuan terhadap minat mahasiswa dalam bekerja tim.

\section{Landasan Teori}

Menurut Yuen \& Majid (2007) kesediaan berbagi pengetahuan merupakan suatu elemen dasar yang efektif dan sangat penting dalam dalam mempelajari yang berkenaan dengan suatu jabatan. Etika yang baik dalam kesediaan berbagi pengetahuan akan membuat mahasiswa memiliki nilai lebih yang sangat berguna dalam dunia kerja (Yuen \& Majid, 2007). Hal ini menyatakan bahwa kesediaan berbagi pengetahuan harus menjadi bagian dari kepribadian dan harus diterapkan menjadi mindset dalam area kerja. Kepercayaan dan kepedulian merupakan elemen yang penting dalam kesediaan berbagi pengetahuan. Dalam penelitian Yuen \& Majid (2007) juga menjelaskan bahwa universitas harus memberikan kesempatan dan situasi informal sebuah tim untuk mahasiswa agar dapat mempelajari pentingnya kesediaan berbagi pengetahuan dalam sebuah kerja tim dan elemen penting yang harus dimiliki setiap mahasiswa dalam dunia kerja. Menurut Fullwood, Rowley, \& Delbridge (2013) kesediaan berbagi pengetahuan akan meningkatkan dan memperluas hubungan dengan rekan mahasiswa dan menawarkan kesempatan untuk promosi jabatan internal dan jabatan eksternal. Penelitian ini juga memahami bahwa kesediaan berbagi pengetahuan harus dimiliki oleh manajer dan mahasiswa.

Menurut Rudawska (2016) setiap mahasiswa yang aktif dalam kegiatan kerja tim sangat memerlukan etika positif sehingga dalam karir profesional masa depan, mahasiswa tersebut tidak akan canggung dalam bekerja tim dan akan menjadi seseorang yang berpengaruh dalam sebuah tim kerja. Sikap bekerja tim mengasumsikan bahwa etika positif berhubungan dengan intensitas dalam bekerja tim dan mampu menjadikan proses kerja tim berjalan dengan baik. Sikap bekerja tim bertujuan untuk bagaimana peran anggota tim membuat kerja tim nya menjadi efektif. Sikap

bekerja tim juga dibutuhkan untuk mengembangkan setiap etika mahasiswa dalam bekerja juga memahami manfaat kerja tim memperoleh ilmu pengetahuan dan kemampuan khusus dalam menyelesaikan setiap permasalahan dalam tim kerja.

Sikap bekerja tim terdapat dua komponen yakni cognitive dan behavioural. Dimana penilaian 
cognitive mengevaluasi pemahaman setiap mahasiswa bahwa mampu memimpin tim kerja dapat memberikan pengaruh kerja yang lebih baik, memunculkan inovasi dan kinerja yang baik untuk anggota tim sehingga dapat mencapai sebuah persepsi keefektivan tim kerja. Kemudian behavioural merupakan komponen dari sikap bekerja tim yang dinilai apakah mahasiswa lebih berminat dalam bekerja tim atau bekerja secara individual.

\section{Metode Penelitian, Hasil dan Pembahasan}

\section{Metode Penelitian}

\section{Jenis dan Sumber Data}

Penelitian ini menggunakan data primer dan jenis data yang digunakan yaitu data kuesioner. Data sampel yang diperoleh bersumber dari kuesioner yang diadaptasi dari kuesioner Yuen

\& Majid (2007) dan Rudawska (2016). Kuesioner akan disebarkan kepada responden sesuai dengan lokasi dan obyek penelitian yang telah ditetapkan dalampenelitian ini yaitu ke beberapa mahasiswa/i program studi akuntansi yang ada di kota Batam.

\section{Variabel Dependen}

Variabel dependen dalam penelitian ini adalah sikap dalam bekerja tim. Dalam variabel ini diukur melalui 2 dimensi yaitu persepsi keefektivan kerja tim dan minat mahasiswa dalam bekerja sama. Semakin tinggi skor sikap bekerja tim maka semakin tinggi positif sikap mahasiswa yang bersangkutan untuk bekerja dalam tim. Sebaliknya semakin rendah skor sikap bekerja tim maka semakin negatif sikap mahasiswa yang bersangkutan untuk bekerja dalam tim (Rudawska, 2016).

\section{Variabel Independen}

Variabel independen dalam penelitian ini adalah kesediaan berbagi pengetahuan. Kesediaan berbagi informasi diukur dengan kuesioner yang digunakan dalam penelitian Yuen \& Majid (2007). Semakin tinggi skor kesediaan berbagi pengetahuan maka semakin tinggi kesediaan mahasiswa yang bersangkutan untuk berbagi pengetahuan. Sebaliknya Semakin rendah skor kesediaan berbagi pengetahuan maka semakin rendah kesediaan mahasiswa yang bersangkutan untuk berbagi pengetahuan.

\section{Teknik Penarikan Sampel}

Teknik penarikan sampel yang digunakan adalah purposive sampling. Kriteria yang diambil oleh peneliti adalah mahasiswa/i yang diteliti harus sudah pernah bekerjasama dalam tim dalam pengerjaan tugas kelompok di kelas dan merupakan mahasiswa/i dalam lingkup jurusan akuntansi. Mahasiswa/i yang menjadi responden merupakan mahasiswa aktif dan bebas berasal dari semester berapa saja dalam ruang lingkup akuntansi.

\section{Tabel 1 Karakteristik Sampel}

\begin{tabular}{lll}
\hline Perguruan Tinggi & Jumlah & Persentase \\
\hline Politeknik Negeri Batam & 40 & 20,0 \\
Universitas Internasional Batam & 40 & 20,0 \\
Universitas Batam & 40 & 20,0 \\
Universitas Riau Kepulauan & 40 & 20,0 \\
Universitas Putera Batam & 40 & 20,0 \\
\hline Total & $\mathbf{2 0 0}$ & $\mathbf{1 0 0 , 0}$ \\
\hline Sumber : Olah Data & &
\end{tabular}

\section{Teknik Pengumpulan Data}

Pengumpulan data dilakukan dengan menyebarkan kuesioner penelitian secara langsung kepada para mahasiswa/i aktif yang ada di kota Batam dengan ruang lingkup jurusan akuntansi.

\section{Teknik Pengolahan Data}

Peneliti melakukan langkah-langkah dalam mengolah data penelitian yang berasal dari hasil kuesioner-kuesioner yang telah diisi oleh responden dan telah dikumpulkan oleh penulis, yaitu

1) Melakukan pengecekan jumlah data kuesioner yang balik kepenulis dan kelengkapan data pada isi kuesioner yang telah diterima dan sesuai dengan kriteria sampel penelitian yang dilakukan;

2) Merekap semua data yang telah diperoleh dengan memasukkan data ke MicrosoftExcel;

3) Mengolah data menggunakan fasilitas komputer dengan aplikasi program SPSS 22. 
Dinda \& Hajan, pengaruh kesediaan berbagi pengetahuan pada sikap dalam bekerja tim...

\section{Teknik Analisis Data}

Pengujian hipotesis penelitian dilakukan dengan menggunakan analisis regresi sederhana dalam program SPSS 20. Sebelum dilakukan analisis regresi tersebut, data harus memenuhi syarat uji kualitas data dan uji asumsi klasik.

\section{Uji Kualitas Data}

Uji Kualitas Data digunakan untuk menguji kecukupan dan kelayakan data yang akan digunakan dalam penelitian. Uji kualitas data yang dilakukan adalah :

\section{Uji Validitas}

Uji validitas dilakukan untuk mengetahui kemampuan instrument penelitian mengukur apa yang seharusnya diukur. Dari hasil tabel uji validitas dapat diketahui bahwa setiap item pernyataan yang digunakan dalam kuesioner memiliki rhitung yang lebih besar dari pada $\mathrm{r}_{\text {tabel. }}$ Hal ini menunjukkan bahwa setiap item pernyataan yang digunakan valid dan bisa digunakan dalam penelitian.

\section{Uji Reliabilitas}

Uji reliabilitas dilakukan dengan tujuan untuk mengukur konsistensi internal alat ukur yang digunakan. Dari hasil uji reliabilitas dapat disimpulkan bahwa kuesioner yang digunakan dalam penelitian sudah dikatakan reliabel karena nilai Cronbach's Alpha dari masing-masing variabel lebih besar dari 0,70 .

\section{Uji Asumsi Klasik}

Uji asumsi klasik digunakan untuk menguji ketepatan model. Uji asumsi klasik yang akan digunakan adalah:

\section{Uji Normalitas}

Uji normalitas data dapat dilihat dengan menggunakan uji normal Kolmogorov-smirnov. Kriteria pengambilan keputusannya adalah jika sig > 0,05 maka data terdistribusi normal dan jika sig < 0,05 maka data tidak terdistribusi normal (Ghozali L. , 2012). Berdasarkan uji normalitas dengan kolmogorov smirnov diperoleh nilai signifikansi $\mathrm{H} 1 \quad 0,200$ dan $\mathrm{H} 2$ 0,200 lebih besar dari 0,05 . Sehingga dapat disimpulkan bahwa data berdistribusi normal.

\section{Uji Heteroskedastisitas}

Uji heteroskedastisitas memiliki nilai signifikan korelasi $>0,05(\alpha=5 \%)$ maka dapat disimpulkan tidak terjadi heteroskedastisitas. Berdasarkan hasil output dari SPSS, diperoleh nilai signifikansi pada $\mathrm{H} 1$ sebesar 0,441 lebih besar dari 0,05 sehingga dapat disimpulkan data terbebas dari masalah heteroskedastisitas. Nilai signifikansi pada $\mathrm{H} 2$ sebesar 0,722 lebih besar dari 0,05 sehingga dapat disimpulkan data terbebas dari masalah heteroskedastisitas.

\section{Analisis Statistik Deskriptif}

Analisis deskriptif yaitu memberikan gambaran atau deskriptif empiris atas data yang dikumpulkan dalam penelitian (Ferdinand, 2000). Data penelitian berasal dari jawabanjawaban responden atas item-item yang terdapat dalam kuesioner, dan akan diperoleh dengan cara dikelompokkan dan ditabulasikan kemudian diberi penjelasan. Statistik deskriptif juga ditujukan untuk memberikan gambaran tentang demografi responden penelitian dan gambaran tentang variabel-variabel penelitian untuk mengetahui distribusi frekuensi absolut yang menunjukkan angka rata-rata (mean) kisaran aktual, penyimpangan baku (standard deviation), dan kecenderungan jawaban responden.

\section{Uji Analisis Regresi Sederhana}

Analisis regresi linear sederhana merupakan analisis hubungan antara variabel dependen dan variabel indepeden (Widarjono, 2015). Ada dua jenis hubungan antara variabel dependen dengan variabel independen didalam analisis regresi yaitu hubungan positif dan hubungan negatif. Hubungan positif antara variabel dependen dan independen terjadi jika kedua variabel bergerak dalam arah yang sama (direct relationship). Ketika variabel independen naik maka variabel dependen juga mengalami kenaikan atau sebaliknya. Hubungan negatif terjadi jika kedua variabel tersebut bergerak dalam arah yang berlawanan ( inverse relationship) (Widarjono, 2015). Dalam analisis regresi, selain untuk mengukur kekuatan hubungan antara dua variabel atau lebih, juga menunjukkan arah hubungan antara variabel dependen dengan variabel independen (Ghozali L. , 2012). Adapun rumus dalam regresi sederhana yaitu $\mathrm{Y}$ $=\alpha+\beta \mathrm{x}$. 


\section{Hasil dan Pembahasan}

\section{Hipotesis}

Proses dalam kesediaan berbagi pengetahuan merupakan suatu hal utama untuk inovasi, pembelajaran organisasi, pengembangan keahlian baru dan kapabilitas, dan meningkatkan produktivitas (Mueller, Luther, \& Halle, 2015).

Dalam praktiknya, kesediaan berbagi pengetahuan memainkan peran penting dalam berkomunikasi. Dalam hal informal komunikasi memainkan perannya dalam hal berapa banyak ilmu yang dishare dalam sebuah tim. Dalam hal formal komunikasi berperan dalam memberikan dokumen, buku, dan hal-hal yang berkaitan dengan kebutuhan kelompok. Menurut Yuen dan Majid (2007) kesediaan berbagi pengetahuan merupakan suatu elemen dasar yang efektif dan sangat penting dalam dalam mempelajari yang berkenaan dengan suatu jabatan. Penelitian tersebut mendapatkan kesimpulan bahwa aktif dan bersedia dalam berbagi informasi adalah sebuah elemen yang esensial dalam keefektivan pembelajaran di setiap jenjang.

Dalam penelitian Rudawska (2016) sikap bekerja tim fokus pada 2 dimensi yaitu, cognitive dan behavioural. Dimensi cognitive digunakan untuk mengevaluasi bagaimana mahasiswa memperluas pengetahuan yang didapatkan berdasarkan efektivitas kerja tim yang dipercaya secara individual bahwa kerja tim membuat efek yang lebih baik bagi anggota tim. Menurut Fahmi (2015) kinerja tim yang efektif harus terdapat kemampuan bekerja dalam tim. Sehingga dapat dicapai suatu kualitas dapat sebuah tim. Kualitas tim kerja yang baik mampu membangun perilaku kelompok yang positif. Dengan demikian, dapat disimpulkan bahwa perilaku yang positif menghasilkan persepsi kinerja tim efektif (Rudawska, 2016).

Dimensi behavioural yaitu mengevaluasi mahasiswa dalam minatnya untuk bekerjasama atau bekerja secara individu. Dikarenakan tidak semua anggota dalam tim pernah bekerja sama. Bila diberikan pilihan, banyak orang yang memilih untuk tidak terlibat dalam suatu tim. Ketika yang lebih suka bekerja secara individu diminta untuk bekerja dalam suatu tim, maka terdapat ancaman moral tim dan kepuasaan anggota. Ini menunjukkan bahwa ketika memilih anggota tim, preferensi (ketertarikan) individual harus dipertimbangkan seperti halnya kemampuan, kepribadian, dan keterampilan. Tim yang berkinerja tinggi cenderung terdiri atas orang-orang yang lebih suka bekerja sama dalam suatu bagian kelompok (Robbins \& Judge, 2011). Tim yang efektif harus memiliki komposisi perilaku yang baik dan ketertarikan anggota dalam berbagi pengetahuan (Robbins \& Judge, 2011).

Berdasarkan uraian diatas maka hipotesis dalam penelitian ini adalah sebagai berikut :

H1: Kesediaan berbagi pengetahuan berpengaruh positif pada persepsi keefektivan kerja tim.

H2: Kesediaan berbagi pengetahuan berpengaruh positif pada preferensi (minat) dalam bekerja tim.

Berdasarkan penjelasan pada bagian sebelumnya, maka model penelitian dapat digambarkan seperti berikut:

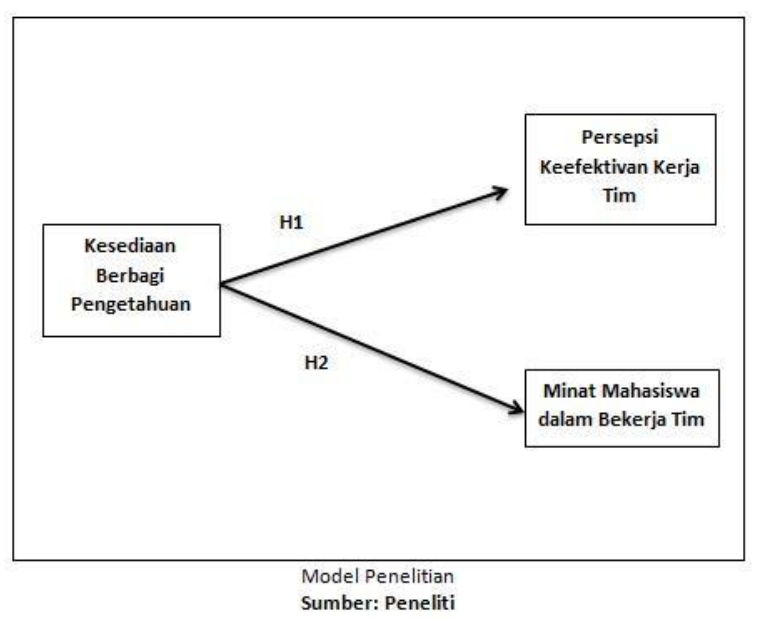

Gambar 1 Model Penelitian

Statistik Deskriptif

Tabel 2 Statistik Deskriptif

\begin{tabular}{llll}
\hline $\begin{array}{c}\text { Statistik } \\
\text { Deskriptif }\end{array}$ & $\begin{array}{c}\text { Total Kesediaan } \\
\text { Berbagi } \\
\text { Pengetahuan }\end{array}$ & $\begin{array}{c}\text { Total Persepsi } \\
\text { Keevektifan Tim } \\
\text { Kerja }\end{array}$ & $\begin{array}{c}\text { Total Minat } \\
\text { dalam } \\
\text { Bekerja Tim }\end{array}$ \\
\hline $\mathrm{N}$ & 200 & 200 & 200 \\
Mean & 23,55 & 19,8 & 16 \\
Std. Deviation & 3,6 & 3,2 & 3,04 \\
Minimum & 17 & 10 & 7 \\
Maximum & 35 & 25 & 23 \\
\hline Sumber: Hasil Olahan SPSS & &
\end{tabular}


Dinda \& Hajan, pengaruh kesediaan berbagi pengetahuan pada sikap dalam bekerja tim...

Berdasarkan tabel 4.9 dapat dilihat bahwa jumlah sampel yang digunakan dalam penelitian ini adalah 200 responden. Variabel independen dalam penelitian ini adalah kesediaan berbagi pengetahuan. Variabel independen tersebut memiliki nilai minimum 17 dan maksimum 35. Rata-rata kesediaan berbagi pengetahuan adalah 23,55 dengan standar deviasi 3,6. Variabel dependen dalam penelitian ini adalah sikap dalam bekerja tim yang terdiri dari dua komponen yaitu persepsi keefektivan tim kerja dan minat dalam bekerja tim. Persepsi keefektivan tim kerja memiliki nilai maksimum 25 dan minimum 10. Rata-rata persepsi keefektivan tim kerja adalah 19,8 dengan standar deviasi 3,2. Minat dalam bekerja tim memiliki nilai maksimum 23 dan minimum 7. Rata-rata minat dalam bekerja tim adalah 16,04 dengan standar deviasi 3,04.

\section{Pengujian Hipotesis}

Pengujian hipotesis dilakukan dengan menggunakan analisis regresi sederhana untuk pengujian hipotesis dengan menggunakan SPSS versi 22. Pengujian dilakukan setelah dilakukan pengujian asumsi klasik hingga dapat disimpulkan bahwa model regresi terbebas dari masalah heteroskedastisitas dan normalitas. Pengujian hipotesis merupakan pembuktian statistik atas dugaan yang telah di hipotesiskan dalam penelitian berdasarkan teori. Untuk menguji hipotesis yang telah diajukan dan untuk mendeteksi pengaruh variabel independen terhadap variabel dependen digunakan metode analisis regresi sederhana.

\section{Hipotesis 1}

Hipotesis pertama yang diajukan dalam penelitian ini menyatakan bahwa kesediaan berbagi pengetahuan berpengaruh positif terhadap persepsi keefektivan kerja tim. Penelitian ini menggunakan sebanyak 200 responden yang diolah menggunakan SPSS dan hasilnya disajikan dalam tabel 3.

\section{Tabel 3 Hasil Analisis Pengaruh Kesediaan Berbagi Pengetahuan terhadap Persepsi Keefektivan Kerja Tim}

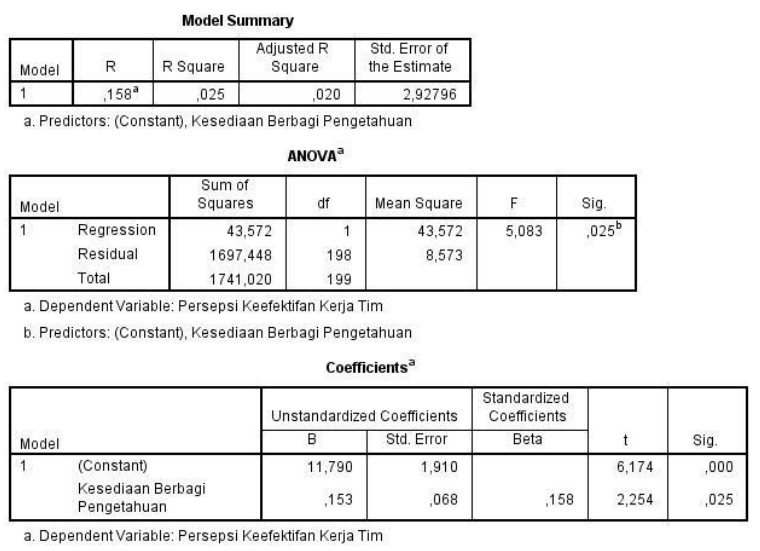

Hipotesis pertama yang diajukan dalam penelitian ini menyatakan bahwa kesediaan berbagi pengetahuan berpengaruh terhadap persepsi keefektivan tim kerja. Hipotesis ini dapat didukung apabila nilai probabilitas signifikansi menunjukan nilai $<0,05$ dan apabila nilai probabilitas signifikansi menunjukkan nilai $>0,05$ maka probabilitas tidak terdukung. Berdasarkan tabel 3 dapat dilihat bahwa nilai probabilitas signifikansi adalah 0,025. Nilai signifikansi tersebut lebih kecil dari 0,05, sehingga dapat disimpulkan bahwa H1 terdukung. Hal ini menunjukkan bahwa kesediaan berbagi pengetahuan berpengaruh positif terhadap persepsi keefektivan tim kerja.

\section{Hipotesis 2}

Hipotesis kedua yang diajukan dalam penelitian ini menyatakan bahwa kesediaan berbagi pengetahuan berpengaruh positif terhadap minat mahasiswa dalam bekerja tim. Penelitian ini menggunakan sebanyak 200 responden yang diolah menggunakan SPSS dan hasilnya disajikan dalam tabel 4. 


\section{Tabel 4 Hasil Analisis Pengaruh Kesediaan Berbagi Pengetahuan terhadap Minat Mahasiswa dalam Bekerja Tim}

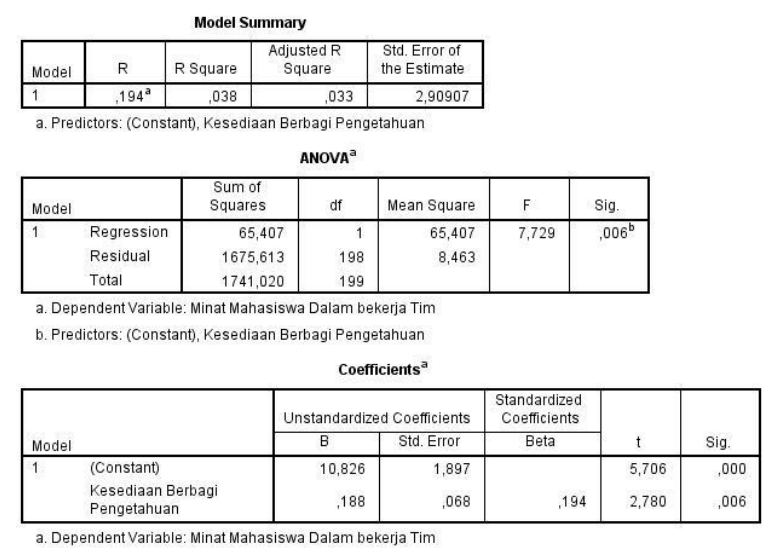

Hipotesis kedua yang diajukan dalam penelitian ini menyatakan bahwa kesediaan berbagi pengetahuan berpengaruh terhadap minat mahasiswa dalam bekerja tim. Hipotesis ini dapat didukung apabila nilai probabilitas signifikansi menunjukan nilai $<0,05$ dan apabila nilai probabilitas signifikansi menunjukkan nilai $>0,05$ maka probabilitas tidak terdukung. Berdasarkan tabel 4 dapat dilihat bahwa nilai probabilitas signifikansi adalah 0,006. Nilai signifikansi tersebut lebih kecil dari 0,05, sehingga dapat disimpulkan bahwa $\mathbf{H 2}$ terdukung. Hal ini menunjukkan bahwa kesediaan berbagi pengetahuan berpengaruh positif terhadap minat mahasiswa dalam bekerja tim.

\section{Analisis Data}

Berikut adalah tabel ringkasan hasil uji hipotesis penelitian pada mahasiswa akuntansi se Kota Batam

Tabel 5 Ringkasan Hasil Uji Statistik

\begin{tabular}{lll}
\hline Hipotesis & Sig & Simpulan \\
\hline H1 Kesediaan berbagi pengetahuan berpengaruh positif & 0,025 & Terdukung \\
terhadap persepsi keefektivan kerja tim & & \\
H2 Kesediaan berbagi pengetahuan berpengaruh positif & 0,006 & Terdukung \\
terhadap minat mahasiswa dalam kerja tim & & \\
\hline Sumber : Hasil Olahan SPSS 22 & &
\end{tabular}

\section{Kesediaaan Berbagi Pengetahuan berpengaruh Positif pada Keefektivan Kerja Tim}

Berdasarkan hasil uji statistik, H1 menunjukkan bahwa kesediaan berbagi pengetahuan berpengaruh positif terhadap persepsi keefektifan kerja tim. Hasil ini menunjukkan bahwa kesediaan berbagi pengetahuan dapat menciptakan persepsi keefektivan tim kerja meningkat. Kesediaan dalam berbagi pengetahuan membuat anggota tim merasa bahwa tim kelompoknya atau tim kerja nya akan efektif apabila anggota timnya bersedia berbagi pengetahuan. Hasil penelitian ini membuktikan bahwa saran dari penelitian Rudawska (2016) terbukti, bahwa kesediaan berbagi pengetahuan berpengaruh positif terhadap persepsi keefektivan kerja tim. Penelitian ini juga sejalan dengan penelitian Yuen \& Majid (2007) bahwa kesediaan berbagi pengetahuan memiliki pengaruh positif terhadap proses belajar mengajar dalam sebuah tim kerja dan merupakan sebuah metode yang efektif dalam pembelajaran sebuah tim. Yuen \& Majid (2007) juga mengatakan bahwa etika yang baik akan membuat mahasiswa memiliki nilai yang lebih berguna dalam dunia kerja. Hal ini menunjukkan bahwa kesediaan berbagi pengetahuan memiliki pengaruh yang positif terhadap persepsi keefektivan kerja tim.

\section{Kesediaan Berbagi Pengetahuan berpengaruh postif pada Minat Mahasiswa dalam Bekerja Tim}

Berdasarkan hasil uji statistik yang telah dijelaskan diatas, menunjukkan bahwa $\mathrm{H} 2$ terdukung, yang berarti terdapat hubungan positif antara kesediaan berbagi pengetahuan terhadap minat mahasiswa dalam bekerja tim. Hasil penelitian ini membuktikan bahwa saran dari penelitian Rudawska (2016) terbukti, bahwa kesediaan berbagi pengetahuan berpengaruh positif terhadap sikap dan minat dalam bekerja tim. Penelitian ini juga sejalan dengan penelitian Yuen \& Majid (2007) bahwa kesediaan berbagi pengetahuan memiliki pengaruh positif terhadap proses belajar mengajar dalam sebuah tim kerja dan merupaka sebuah metode yang efektif dalam 
Dinda \& Hajan, pengaruh kesediaan berbagi pengetahuan pada sikap dalam bekerja tim...

pembelajaran sebuah tim. Hal ini menunjukkan bahwa kesediaan berbagi pengetahuan memiliki pengaruh yang positif terhadap minat mahasiswa bekerja dalam sebuah tim.

\section{Kesimpulan}

Penelitian ini bertujuan untuk menganalisis pengaruh antara kesediaan berbagi pengetahuan terhadap persepsi keefektivan tim kerja dan pengaruh antara kesediaan berbagi pengetahuan terhadap minat mahasiswa dalam bekerja tim. Sampel yang digunakan dalam penelitian ini adalah mahasiswa akuntansi di perguruan tinggi se kota Batam. Uji Hipotesis dalam penelitian ini menggunakan analisis regresi sederhana dengan bantuan program SPSS 22. Hasil penelitian ini menunjukkan bahwa:

a. Kesediaan berbagi pengetahuan memiliki pengaruh positif terhadap persepsi keefektivan kerja tim dan minat mahasiswa dalam bekerja tim. Hal ini sejalan dengan penelitian Yuen \& Majid (2007) yang menemukan bahwa kesediaan berbagi pengetahuan memiliki pengaruh yang positif dalam proses belajar mengajar dalam sebuah tim kerja.

b. Hasil penelitian ini dapat melengkapi penelitian Rudawska (2016) yang menyarankan penelitian selanjutnya memiliki pengaruh terhadap kesediaan berbagi pengetahuan terhadap persepsi keefektivan kerja tim dan sikap dan minat dalam bekerja tim.

c. Hal ini menunjukkan bahwa kesediaan berbagi pengetahuan mampu memberikan pengaruh yang positif terhadap minat mahasiswa dalam bekerja tim dan persepsi keefektivan kerja tim.

\section{Keterbatasan dan Saran}

Penelitian ini hanya menggunakan kesediaan berbagi pengetahuan dalam variabel independen. Penelitian ini juga hanya menggunakan sampel mahasiswa akuntansi di perguruan tinggi se kota Batam.

Penelitian ini dapat dijadikan bahan pertimbangan sebagai referensi atau tambahan informasi bagi peneliti yang akan melakukan penelitian selanjutnya mengenai kerja tim. Hasil penelitian ini menunjukkan bahwa kesediaan berbagi pengetahuan mempengaruhi minat mahasiswa dalam bekerja tim artinya mahasiswa akan memiliki minat dalam bekerja tim apabila dalam sebuah tim terdapat kesediaan berbagi pengetahuan antar sesama anggota tim. Penelitian ini menemukan hal yang sama dalam efektifitas tim, dimana kesediaan berbagi pengetahuan memiliki pengaruh yang positif terhadap persepsi keefektivan tim kerja, artinya mahasiswa memiliki pemikiran jika antar angota tim bersedia berbagi pengetahuan maka mampu menciptakan keefektivan sebuah tim kerja.

Sehingga penelitian ini menyarankan untuk penelitian selanjutnya dapat menambahkan variabel lain dalam penelitian ini seperti variabel kepercayaan dan perilaku individu dalam keseharian bekerja tim dan dapat melakukan pada sampel yang lebih luas, misalnya mahasiswa akuntansi se Kepulauan Riau.

\section{Daftar Pustaka}

Agus Widarjono, P. (2015). Statistika Terapan Dengan Excel \& SPSS. Yogyakarta.

Cha, M., \& Park, J.-G. (2017). Effects of team member psychological proximity on teamwork performance. Team Performance Management, pp. 81-96 Vol. 20 Issue $1 / 2$.

Constantin, Geta, A., \& Meier, E. (2014). The challenges of accounting profession. Theoritichal and Applied Economics, 4356.

Ghozali. (2012). Aplikasi Analisis Multivariate dg Program IBM SPSS 20.

Irham Fahmi, S. M. (2016). Perilaku Organisasi (Teori, Aplikasi, dan Kasus). Bandung: Penerbit Alfabeta.

Jackling, R. P. (2016). Teamwork from accounting graduates : What do employers really expect. Accounting Research Journal, - .

Kiffin, S. A., Petersen, \& Cordery, J. L. (2003). Trust, individualism and job characteristics as predictors of employee preference for teamwork. International Journal of Human Resource Management, 93-116. 
Mohammed, A. F. (2010). Profesional atitudes towards teamwork in the social welfare organizations.

Mueller, J., Luther, M., \& Halle. (2015). Formal and Informal Practices of Knowledge Sharing Between Project Teams and Enacted Cultural Characteristic. Project Management Journal, 53-68.

Park, R. (2012). Self-managing teams and employee attitudes: the moderating role of capital intensity. The International JOurnal of Human Research Management, 714-730.

Pineda, R. C., \& Lerner, L. D. (2006). GGoal Attainment, satisfaction and learning from teamwork. Team Performance Management, 182-191.

Prof. Dr. Jogiyanto Hartono, M. A. (2011). Metodologi Penelitian Bisnis (Salah Kaprah dan Pengalaman-Pengalaman). Yogyakarta: Fakultas Ekonomika dan Bisnis UGM.

Robbins, S. P., \& Judge, T. A. (2011) Organizational Behaviour. United States, America: Pearson.

Rudawska, A. (2016). Students' Team Project Experiences and Their Attitudes Towards Teamwork. Journal of Management and Business Administration, 78-97.

Siha, S., \& Campbell, S. M. (2015). Teamwork : Faculty and Student Experience. BQuest, PI-21-21P.

Tsui,L.,Chapman,S.A.,Schnirer,L.,\& Stewart, S. (2006). A Handbook on Knowledge Sharing: Strategies and Recommendations for Researchers, Policymakers, and Service Providers. Edmonton: Community University Partnership.

Turaga, R. (2013). Building Trust in Team: A Leader's Role. The Journal of Softskills.

Ulloa, B. C., \& Adams, S. G. (2004). Attitude Towards Teamwork \& Effective Teaming. Tam Performance Management: An International Journal, 145-151. 